\section{Bentonite-based organoclays using chalcone and azo dye as organophilic reagents}

Manar Ghyath ABD-ALMUTALIB AL-MOSAWY - Department of Chemistry, Faculty of Science, University of Kufa $\cdot$ manarghyth@yahoo.com

Emad A. JAfFAR AL-MULLA - Department of Chemistry, Faculty of Science, University of Kufa

- imad.almulla@uokufa.edu.iq

MAJED JARI MOHAMAD - Department of Chemistry, Faculty of Science, University of Kufa

Érkezett: 2017. 03. 20. - Received: 20. 03. 2016. " https://doi.org/10.14382/epitoanyag-jsbcm.2017.9

\begin{abstract}
Organoclays (OBNTs) was prepared using two new organic surfactants including 3-(4-aminophenyl)1-(4-chlorophenyl)prop-2-en-1-on $(\mathrm{CH})$ synthesized from a Claisen-Schmidt condensation reaction between p-aminoacetophenone and p-chloro benzaldehyde; and 4-((4-nitrophenyl) diazenyl)-N-(pyrimidin-2-yl) (AZ) prepared from reaction sulfadiazine and p-nitoaniline. OBNTs were characterized by Fourier Transform infrared spectroscopy (FTIR) to evaluate the incorporation above surfactants in bentonite. The X-ray diffraction (XRD) technique was utilized to indicate the basal spacing of the treated clay as a measure of susceptibility of new organo clays. The FTIR and XRD results show that the OBNTs were successfully incorporated in the bentonite clay. Thermogravimetric analysis (TGA) was also used to determine thermal stability. An enhancement in stability was observed in OBNTs compare to pure bentonite. OBNTs prepared in this study can be used to produce disposable packaging polymer nanocomposite.

Keywords: sodium bentonite, modification, surfactants, organic cations
\end{abstract}

Manar Ghyath ABD-ALMUTALIB AL-MOSAWY is a PhD student at Department of Chemistry, Faculty of Science, University of Kufa, Iraq; She has received her MSc from Faculty of Education for Girls, University of Kufa, Iraq in 2010. Main

fields of interest: organic synthesis, nanomaterials, biopolymer nano-composites. She has published many scientific papers in citation and non-citation indexed journals .

Emad Abbas Jaffar AL-MULLA is an Asst. Prof., College of Health and Medical Techniques, Al-Furat Al-Awsat Technical University, Iraq; He has received his PhD from University Putra Malaysia, Malaysia in 2010, He was a Post Doctoral researcher at the same University from April 2012 to April 2013; main fields of interest: bioorganic synthesis, nanomaterials, biopolymer nano-composites; He has more than 50 papers in Scopus and ISI journals; his H-Index $=14$ according to Scopus database.

Majed Jari MOHAMAD is an Asst. Prof., Department of Chemistry, Faculty of Science, University of Kufa, Iraq; He has received his PhD from University of Baghdad, College of Education for Pure Science, Ibn al-Haytham, Department of Chemistry in 2006. Main fields of interest: organic synthesis, nano-materials, heterocyclic compounds. He has published many scientific papers in citation and non-citation indexed journals.

\section{Introduction}

Bentonite, which is predominantly amontmorillonitic clay, is characterized by one $\mathrm{Al}$ octahedral sheet placed between two $\mathrm{Si}$ tetrahedral sheets. The isomorphous substitution of $\mathrm{Al}^{3+}$ for $\mathrm{Si}^{4+}$ in the tetrahedral layer and $\mathrm{Mg}^{2+}$ for $\mathrm{Al}^{3+}$ in the octahedral layer results in a netnegative surface charge on the clay. This charge imbalance is offset by exchangeable cations typically $\mathrm{Na}^{+}$and $\mathrm{Ca}^{2+}$ at the clay surface. The layered structure of the clay allows expansion after wetting. $\mathrm{Na}^{+}$and $\mathrm{Ca}^{2+}$ are strongly hydrate in the presence of water, resulting in ahydrophilic environment at the clay surface [1]. However, cation-exchange reaction have been traditionally exploited as an effective method to replace these inorganic ions with organic cationic surfactant molecules, which intercalate into the clay gallery, resulting in expansion of the interlayer spacing and leading to an increase in the basal spacing. These organic cations render the surface of the clay mineral hydrophobic, leading to the increase of the clay wettability and providing favourable interactions with organic molecules. Both organic-modified and unmodified clays have been used for different industrial applications such as rheological additives, thickeners in coating products glues, plastisols, drilling fluids and cosmetics $[2,3]$. Recently, clays were used in the field of materials science such as solid phase polymeric nanocomposites. In the 1990's, the use of organically modified clays in the polymer-clay nanocomposites has attracted researchers into this area of materials science and technology [4]. The organic modification of clay minerals leads to a decrease in surface energy making clays compatible with polymers. The surface energy of clay minerals and polymer can be determined from contact angle measurements $[5,6]$ reported that melt processed nylon 6-clay nanocomposites was prepared using organoclay. Based on $\mathrm{X}$-ray diffraction analysis, various arrangement of alkyl chains in organoclays had proposed by Lagaly (1986). Novel organo montmorillonites have been synthesized and characterized using different ammonium compounds $[7,8]$. In this study, two new different ammonium compounds 3-(4-aminophenyl)1-(4-chlorophenyl)prop-2-en-1-on (CH) and 4-((4-nitrophenyl) diazenyl)- $N$-(pyrimidin-2-yl) (AZ) were used to modify the compatibility of bentonite clay. These organo-bentonites can be used in various research and industrial application specially polymer nanocomposites.

\section{Experimental}

\subsection{Materials}

Hydrochloric acid from J.T. Baker,USA. p-amino acetophenone were obtained from Fluka andpchlorobenzaldehyde were obtained from Fluka sodium hydroxide were obtain from B.D.H.

\subsection{Characterization}

Organoclay were characterized using two different techniques including X-Ray Diffraction (XRD) and Fourier Transform Infrared spectroscopy(FTIR).

\subsubsection{X-ray diffraction (XRD) analysis}

$\mathrm{X}$-ray diffraction (XRD) study was carried out using a Shimadzu XRD 6000 diffractometer with $\mathrm{Cu} \mathrm{K}$ radiation $(\mathrm{k}$ $=0.15406 \mathrm{~nm}$ ). The diffractogram was scanned in the ranges from $2^{\circ}$ to $10^{\circ}$ at a scan rate of $1^{\circ} / \mathrm{min}$. 


\subsubsection{Fourier-transform infrared (FT-IR) spectroscopy}

The FTIR spectra of the blends samples were recorded by the FTIR spectrophotometer (Perkin Elmer FT-IR-Spectrum BX, USA) using $\mathrm{KBr}$ disc technique. Measurements were made at the faculty of Pharmacy, University of Kufa.

\subsubsection{Nuclear magnetic resonance (NMR)}

The ${ }^{1} \mathrm{H}$ - NMR and ${ }^{13} \mathrm{C}-\mathrm{NMR}$ spectra were obtained with Bruker, Ultra Shield $300 \mathrm{MHZ}$, using DMSO as solvent and TMS as an internal standard.

\subsubsection{Thermogravimetric analysis (TGA)}

TGA was recorded by thermal gravimetric analyser, STA PT1000 Iinseis TGA, Germany, Measurements were made at the College of Education for Sciences Ibn Al-Haitham, University of Baghdad.

\subsection{Preparation of Chalcone}

Amixture of p-aminoacetophenone (1 mmol) $0.5 \mathrm{~g}$, p-chlorobenzaldehyde $1 \mathrm{mmol}$, was treated a $10 \% \mathrm{NaOH}$ aqueous solution $0.5 \mathrm{~mL}$, and $99 \% \mathrm{EtOH} 5 \mathrm{~mL}$. The mixture was stirred at room temperature for $4 \mathrm{hrs}$. The solid formed was filtered then washed with ethanol and water $5 \mathrm{~mL}$. Recrystallization from $99 \%$ ethanol afforded (97\% yield, yellow solid, m.p. $160-165^{\circ} \mathrm{C}$ ) [9].

\subsection{Preparation of AZO}

$2 \mathrm{gm}$ ( 0.0145 mole) of 4- nitro anilin was dissolved in $3 \mathrm{ml}$ of concentrated hydrochloric acid and $15 \mathrm{ml}$ of distilled water. The mixture was cooled at $0-5{ }^{\circ} \mathrm{C}$ in ice-water bath, Then a solution of sodium nitrite $(0.0145$ mole) 0.9 gm was dissolved in 5 mLof distilled water then it will be cooled at $\left(0-5^{\circ} \mathrm{C}\right)$. This solution was added a drop wise to the mixture with stirring at the same temperature. The diazonum salt solution was added portion wise to solution of $(0.0145 \mathrm{~mol}) 3.62 \mathrm{~g}$ sulfadiazine in distilled water with sodium hydroxide 1.5 gmdissolved in $100 \mathrm{~mL}$ distilled water. The $\mathrm{pH}$ was maintained with 6-7 and temperature at $0-5^{\circ} \mathrm{C}$. The mixture was stirred for 30 minutes. The mixture was left over night. The product was precipitated and filtered, washed well with sodium bicarbonate and distilled water andre-crystallized from ethanol (yield 95\%, brown solid, m.p. 193-198 ${ }^{\circ} \mathrm{C}$ ) [10].

\subsection{Preparation of organoclays (OBNT)}

Organoclay was prepared in an aqueous solution. Sodium Bentonite (Na-BNT) $4.00 \mathrm{~g}$ was stirred vigorously in 600 $\mathrm{mL}$ of hot distilled water for $1 \mathrm{~h}$ to form a clay suspension. Subsequently, 3-(4-aminophenyl)-1-(4-chlorophenyl)prop-2-enlon $(\mathrm{CH})$ and 4-((4-nitrophenyl)diazenyl)- $N$-(pyrimidin-2-yl) (AZ) $4.50 \mathrm{~g}$, which had been dissolved in $400 \mathrm{~mL}$ of hot water and concentrated hydrochloric acid $16.00 \mathrm{~mL}$ was added into the clay suspension of. After being stirred vigorously for $1 \mathrm{~h}$ at $80{ }^{\circ} \mathrm{C}$, the organoclay suspension was filtered and washed with distilled water until no chloride was detected with a $1.0 \mathrm{M}$ silver nitrate solution. It was then dried at $60^{\circ} \mathrm{C}$ for $72 \mathrm{~h}$ [11]. The dried organoclay was ground until the particle size was $100 \mu \mathrm{m}$ before the preparation of the nanocomposite $[12,13]$. Table 1 shows the structures of two organoclays.

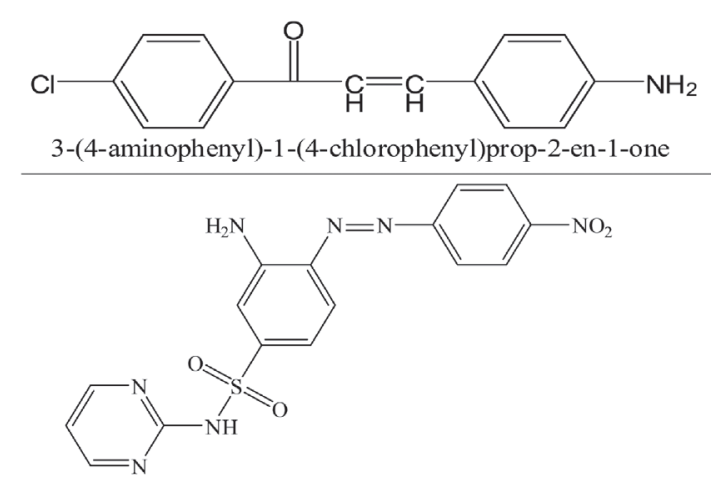

3-amino-4-((4-nitrophenyl)diazenyl)- $N$-(pyrimidin-2-yl)benzenesulfonamide

Table 1. Structure of the two organoclays

1. táblázat A két szerves agyag szerkezete

\section{Results and discussion}

\subsection{X-ray diffraction (XRD) analysis}

The alkyl ammonium cation exchange enable the conversion of the hydrophilic interior clay surface into the hydrophobic surface and consequently increase the layer distance as well [14]. In this study, Na-BNT was surface treated with 3-(4-aminophenyl)-1-(4-chlorophenyl)prop-2-en-1on (CH) and 4-((4-nitrophenyl)diazenyl)-N-(pyrimidin-2-yl) (AZ) as intercalation agent through cation exchange process. The cationic head groups of the intercalation agent molecule would preferentially reside at the layer surface and the tail of the compound will radiate a ways from the surface. The presence of these chains in the galleries makes the originally hydrophilic silicate to organophilic and thus increase the layer-to-layer spacing of Na-BNT [15]. The obtained 3-(4-aminophenyl)-1(4-chlorophenyl)prop-2-en-1on-BNT and 4-((4-nitrophenyl) diazenyl)-N-(pyrimidin-2-yl)-BNT were studied by using X-ray diffraction measurements in the $2 \Theta$ ranges from $2 \Theta-10 \Theta . \mathrm{Na}-$ BNT shows diffraction peak at $2 \Theta=7.0762$ which assigns to the interlayer distance of the natural Bentonite with a basal spacing of $1.25 \mathrm{~nm}$ as known in Fig. 1 [16]. After the ion exchange reaction, the basal spacing (d001value) increase from 1.25-1.77 for 3-(4-aminophenyl)-1-(4-chlorophenyl)prop2-en-1on-BNT and 4-((4-nitrophenyl)diazenyl)-N-(pyrimidin$2-y l)-\mathrm{BNT}$ respectively, suggesting that $\mathrm{CH}^{+}, \mathrm{AZ}^{+}$have been intercalated into the $\mathrm{Na}-\mathrm{BNT}$ galleries. These results are summarized in Table 2. Thus, X-ray diffraction results indicate that are successfully intercalated into the silicate layer.

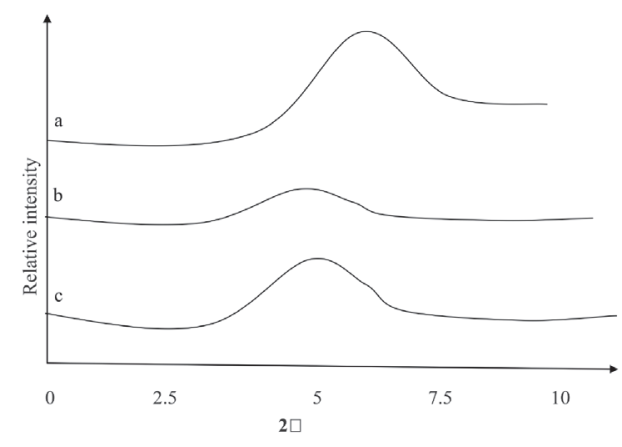

Fig. 1. XRD patterns of (a) Na-BNT; (b) CH-BNT; (c) AZ-BNT 1. ábra Röntgendiffraktogramok (a) Na-BNT; (b) CH-BNT; (c) AZ-BNT 


\begin{tabular}{lccc}
\multicolumn{1}{c}{ Sample } & exchange change & $\mathbf{2 0}\left(^{\circ}\right)$ & d spacing (nm) \\
Bentonite & $\mathrm{Na}^{+}$ & 7.08 & 1.25 \\
\hline CH-modified & $\mathrm{C}_{15} \mathrm{H}_{9} \mathrm{ClO} \mathrm{NH}_{3}{ }^{+}$ & 4.99 & 1.77 \\
\hline AZ-modified & $\mathrm{C}_{16} \mathrm{H}_{9} \mathrm{~N}_{5} \mathrm{O}_{4} \mathrm{SNH}_{3}{ }^{+}$ & 5.01 & 1.76 \\
Table 2. & $\begin{array}{l}\text { Diffraction angle and basal spacing of montmorillonite and modified } \\
\text { montmorillonite with different organic cations }\end{array}$ \\
2. táblázat & $\begin{array}{l}\text { Montmorillonit és modifikált montmorillonit diffrakciós szöge } \\
\text { és bázistávolsága különbözö szerves kationokkal }\end{array}$
\end{tabular}

\subsection{Fourier transform infrared (FTIR) spectroscopy}

FTIR spectroscopy is a useful technique to verify the presence of $\mathrm{CH}^{+}$and $\mathrm{AZ}^{+}$in the clay, respectively. Fig. 2 shows the FTIR spectra of Na-BNT, pure $\mathrm{CH}$ and CH-BNT. Fig. 3 shows the FTIR spectra of Na-BNT, pure AZ and AZ-BNT. The infrared spectrum of the Na-BNT shows two peaks, which correspond to $\mathrm{Si}-\mathrm{O}$ stretching at $1047 \mathrm{Cm}^{-1}$ and interlayer water deformation vibrational $1645 \mathrm{Cm}^{-1}$ [17]. $3628 \mathrm{Cm}^{-1}$ result from the $\mathrm{O}-\mathrm{H}$ stretching vibration. The peaks observed in the CH-BNT (2850-2920 $\left.\mathrm{Cm}^{-1}\right)$ and AZ-BNT (2872-2939 $\mathrm{Cm}^{-1}$ ) infrared spectra correspond to the presence of the $\mathrm{C}-\mathrm{H}$ asymmetric and symmetric stretching vibration, respectively.
In the spectra of $\mathrm{CH}-\mathrm{BNT}$ and AZ-BNT, the absorption bands 3626 and $3640 \mathrm{Cm}^{-1}$ indicate the presence of free $\mathrm{O}-\mathrm{H}$ stretching and at 1091 and $1109 \mathrm{Cm}^{-1}$ correspond to C-N stretching, respectively [18] in addition to the bands of the original Na-BNT. The band at 1490 and $1438 \mathrm{Cm}^{-1}$ suggests the existence of the ammonium ion. Therefore, these indicate that of $\mathrm{CH}^{+}$and $\mathrm{AZ}^{+}$were intercalated in the silicate layers. This suggests that $\mathrm{CH}$ and $\mathrm{AZ}$ are absorbed into the silicate layers of Na-BNT.

\subsection{Nuclear magnetic resonance}

Nuclear magnetic spectroscopy is a useful technique to verify the presence of the ${ }^{1} \mathrm{H}-\mathrm{NMR}$ spectra of $\mathrm{CH}$ pure and AZ pure (Fig. 4), and the ${ }^{13} \mathrm{C}$-NMR spectra of $\mathrm{CH}$ pure and AZ pure (Fig. 5). The nuclear magnetic spectrum of $\mathrm{CH}$, which ${ }^{1} \mathrm{H}-\mathrm{NMR}(300 \mathrm{MHz}, \mathrm{DMSO})$ appearance of multiple signals at the site 6.6-7.8 ppm date back to protons benzene rings, also showed referring at the site $5.3 \mathrm{ppm}$ back to protons $\left(\mathrm{NH}_{2}\right)$ and appearance signals at the site 7.5-7.9 ppm back to protons $(\mathrm{CH}$ $=\mathrm{CH}) .{ }^{1} \mathrm{H}$-NMR spectra of AZ appearance of multiple signals at the site 7.6-8.5 ppm date back to protons benzene rings, also showed referring at the site $6.5 \mathrm{ppm}$ back to protons $\left(\mathrm{NH}_{2}\right)$ and
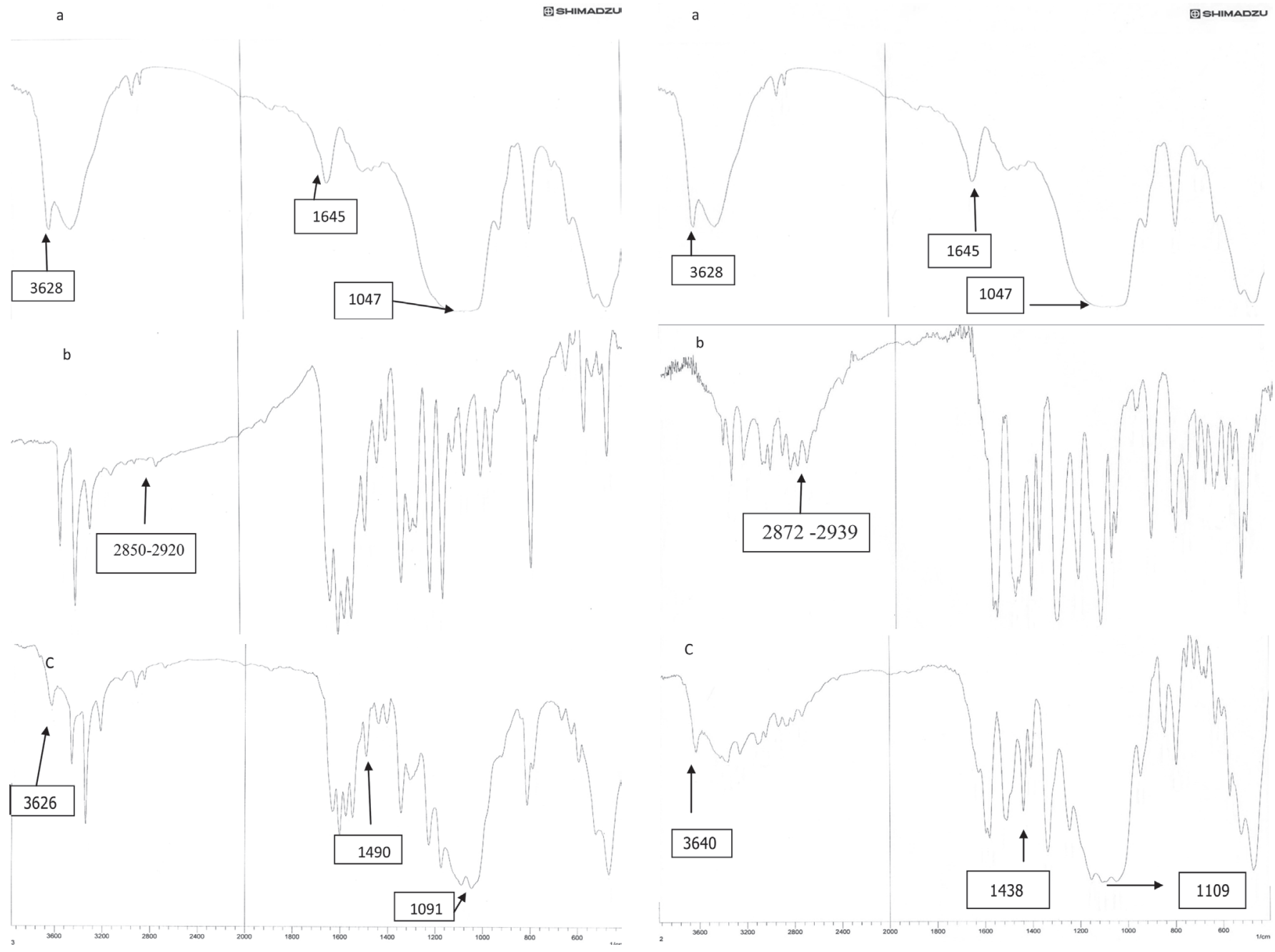

Fig. 2. FTIR Spectra of (a) Na-BNT; (b) CH; (c) CH-BNT 2. ábra FTIR spektrumok (a) Na-BNT; (b) $\mathrm{CH}$; (c) CH-BNT 
a
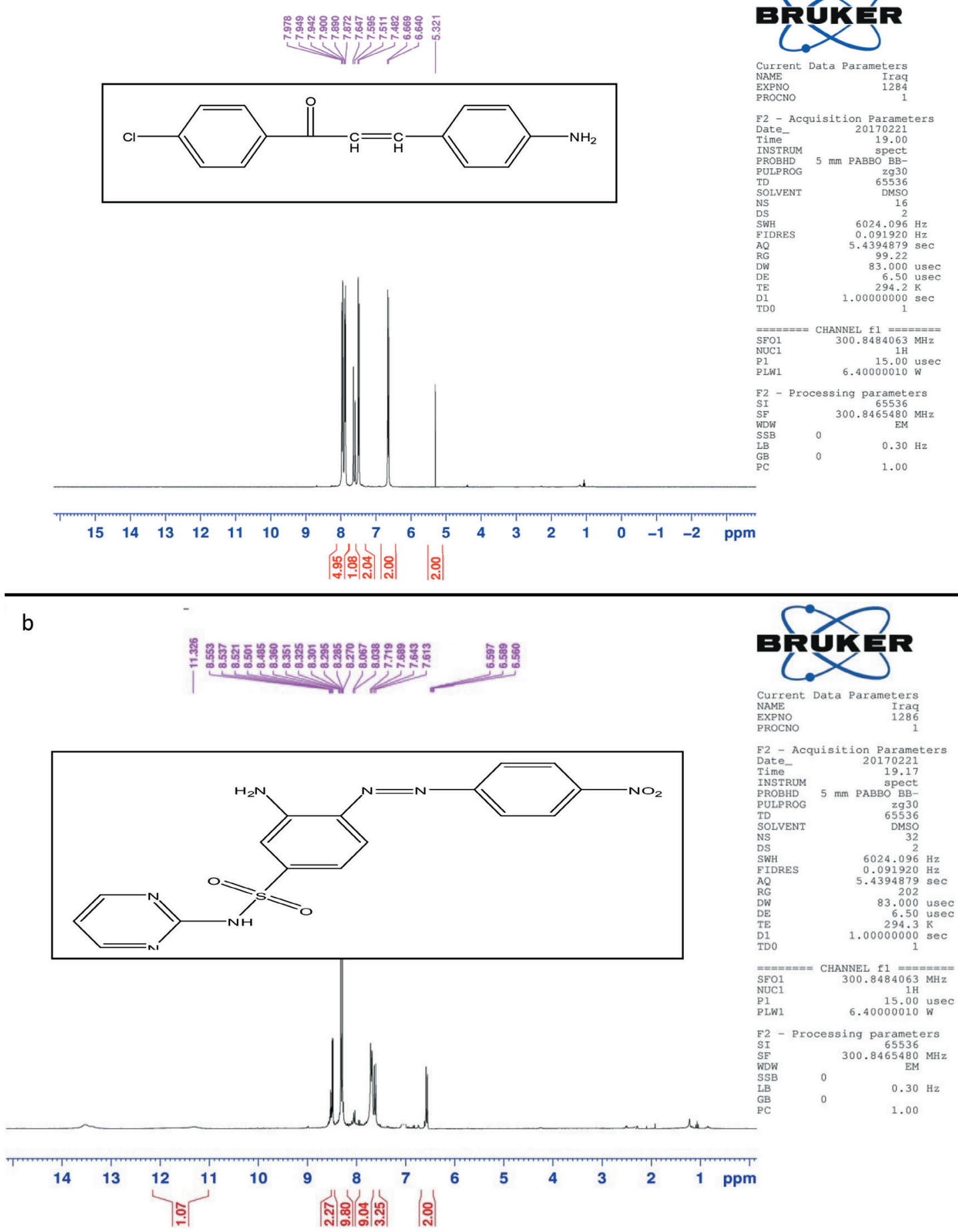

Fig. 4. H-NMR Spectra of (a) $\mathrm{CH}$; (b) $\mathrm{AZ}$

4. ábra H-NMR spektrumok (a) $\mathrm{CH}$; (b) $\mathrm{AZ}$

appearance signals at the site $11.32 \mathrm{ppm}$ back to protons $(\mathrm{NH})$ in sulfadiazine. The nuclear magnetic spectrum of $\mathrm{CH}$, which ${ }^{13} \mathrm{C}$-NMR (300 MHz, DMSO) appearance of multiple signals at the site 113.2-130.6 ppm date back to carbons benzene rings, also showed referring at the site $186.2 \mathrm{ppm}$ back to carbon $(\mathrm{C}=\mathrm{O})$ and appearance signals at the site $145.2-123.6 \mathrm{ppm}$ back to carbon $(\mathrm{CH}=\mathrm{CH}) .{ }^{13} \mathrm{C}-\mathrm{NMR}$ spectra of $\mathrm{AZ}$ appearance of multiple signals at the site $115.9-165.134 \mathrm{ppm}$ date back to carbon benzene rings.

\subsection{Thermogravmetric analysis (TGA)}

Fig. 6 shows the weight loss curves for increasing temperatures of Na-BNT, CH-BNT, AZ-BNT.

Thermogravimetric analysis (TGA) gives information on the structure of the intercalating molecules by the weight loss steps. Thermal degradation of BNT shows before $200{ }^{\circ} \mathrm{C}$ because of the volatilization of water adsorbed on the external surfaces of the BNT and water inside the interlayer space. 
The thermal degradation of the modified BNT can be explained occurs at below $200{ }^{\circ} \mathrm{C}$ due to the vaporization of water.

The weight loss curves (TGA) of the BNT, $\mathrm{CH}-\mathrm{BNT}$ and AZ-BNT were illustrated in Fig. 6. BNT contains water due to hydrated sodium $\left(\mathrm{Na}^{+}\right)$cations intercalated inside the clay layers. The presence of alkyl ammonium groups within the BNT interlayer spacing lowers the surface energy of the inorganic structure and will transform organophobic to organophilic materials.

a

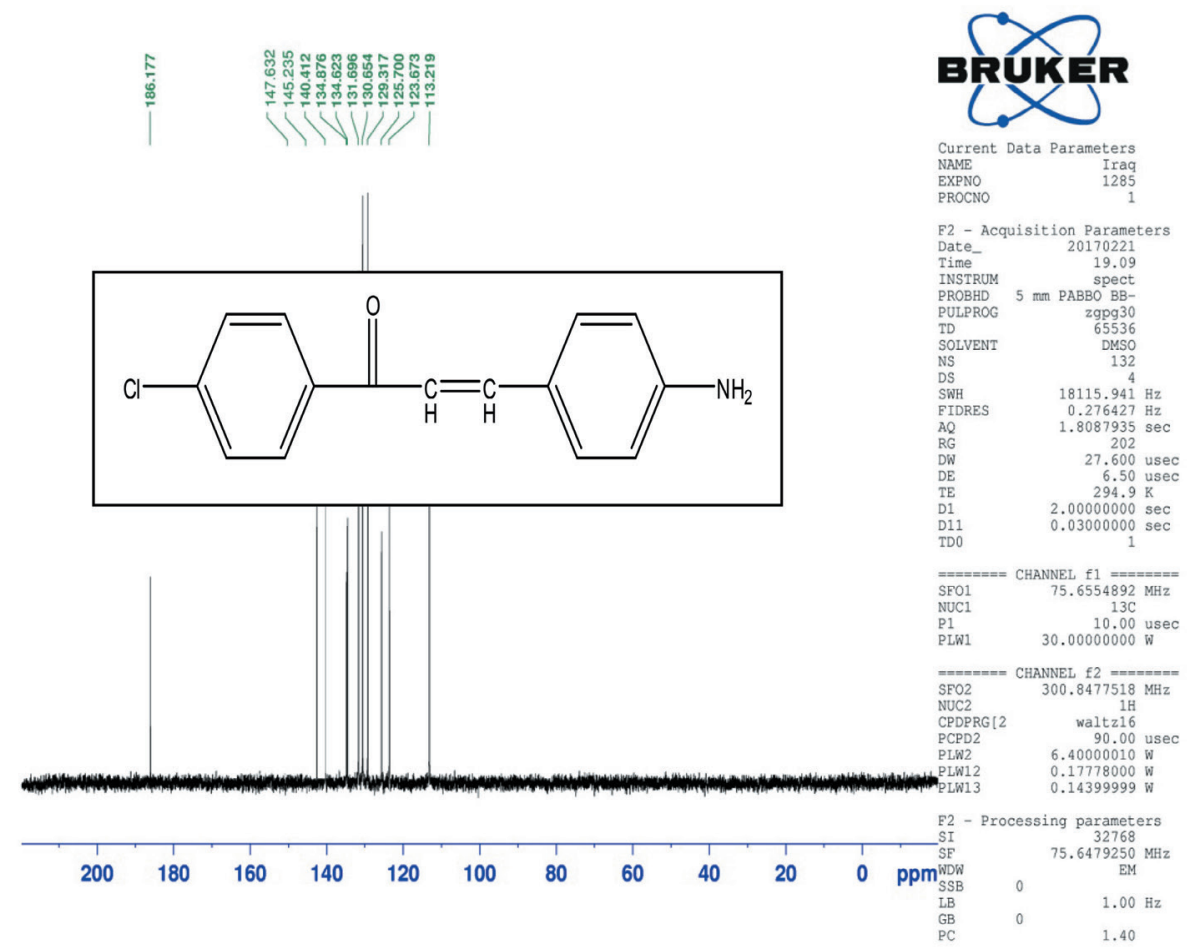

b
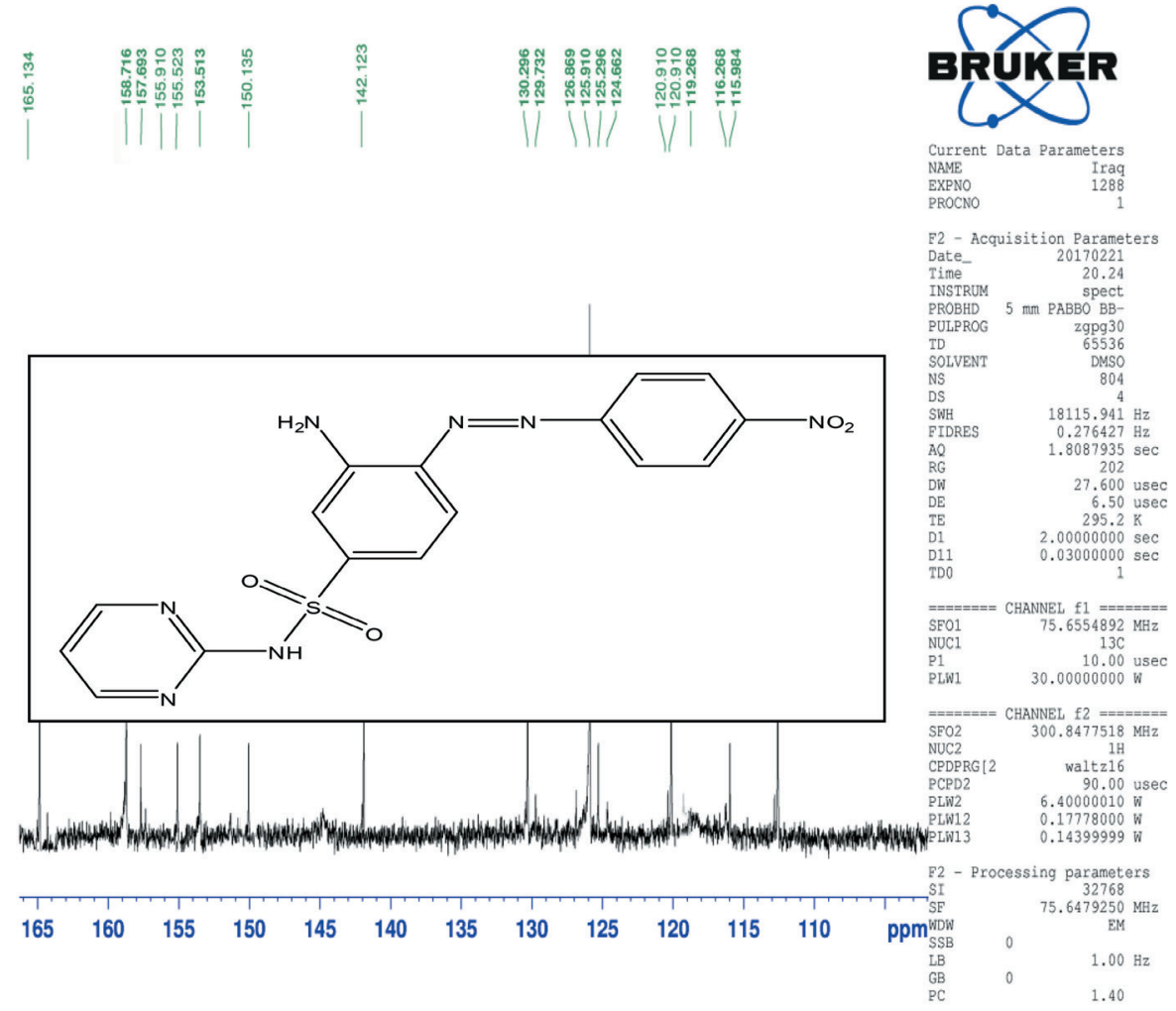
The major difference between the thermogram of the unmodified clay and that of the organoclay is that the organic constituents in the organoclay decompose in the range from 180 to $500{ }^{\circ} \mathrm{C}$, as the organic constituent in the organoclay decomposes in this range.

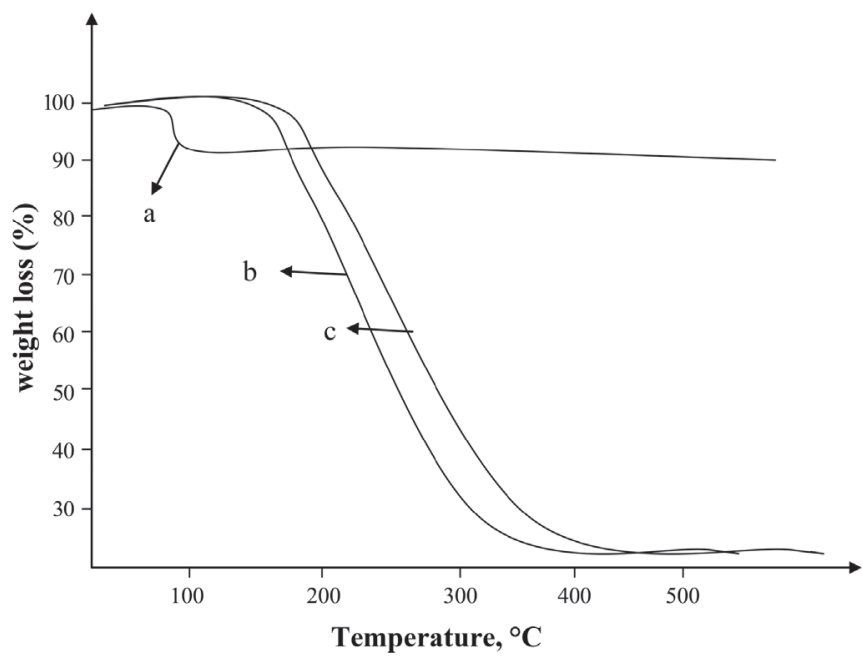

Fig. 6. TGA of (a) Na-BNT; (b) CH-BNT; (c) AZ-BNT

6. ábra TGA görbék (a) Na-BNT; (b) CH-BNT; (c) AZ-BNT

\section{Conclusions}

Two new ammonium cations $\mathrm{CH}$ and $\mathrm{AZ}$ were used to modify bentonite clay in an attempt to create susceptible clay to polymers. The organoclays were characterized using FTIR, $\mathrm{XRD},{ }^{1} \mathrm{HNMR},{ }^{13} \mathrm{CNMR}$ and TGA. Based on result of this study, the following conclusion can be drawn:

- These ammonium cations can be successfully incorporated in the bentonite clay.

- The basal spacing of the bentonite clay increases as a result of incorporating $\mathrm{CH}$ and $\mathrm{AZ}$.

- The new organoclay can be susceptible to polymers.

- Thermal stability was enhanced by incorporation of clay into $\mathrm{CH}$ and $\mathrm{AZ}$.

\section{References}

[1] Yun-Hwei S. (2001): Preparations of organobentonite using nonionic surfactants. Chemosphere, Vol. 44, No. 5, pp. 989-995.

https://doi.org/10.1016/S0045-6535(00)00564-6

[2] Motawie, A. M. - Madany, M. M. - El-Dakrory, A. Z. - Osman, H. M. Ismail, E. A. - Badr, M. M. - El-Komy, D. A. - Abulyazied, D. E. (2014): Physico-chemical characteristics of nano-organo bentonite prepared using different organo-modifiers. Egyptian Journal of Petroleum, Vol. 23, No. 3, pp. 331-338. https://doi.org/10.1016/j.ejpe.2014.08.009

[3] Jaynes, W. F. - Boyd S. A. (1991): Clay mineral type and organic compound sorption by hexadecyltrimethyl ammonium exchanged clays. Soil Science Society of America Journal, Vol. 55, No. 1, pp. 43-48.

[4] Zhang, J. - Wilkie, C. A. (2003): Preparation and flammability properties of polyethylene-clay nanocomposites. Polymer Degradation and Stability, Vol. 80, No. 1, pp. 163-169. https://doi.org/10.1016/S0141-3910(02)00398-1

[5] Maiti, M. - Bhowmick, A. K. (2005): Structure and properties of some novel fluorolastomer/clay nanocomposites with special reference to their interaction. Journal of Polymer Science, Part B, Polymer Physics, Vol. 44, No. 1, pp. 162-176. https://doi.org/10.1002/polb.20680

[6] Dutta, A. - Singh, N. (2015): Surfactant-modified bentonite clays: preparation, characterization, and atrazine removal. Environmental
Science and Pollution Research, Vol. 22, No. 5, pp. 3876-3885. https://doi.org/10.1007/s11356-014-3656-3

[7] Motawie, M. A. - Ahmed, N. M. - El Mesallamy, S. M. - Sadek, E. M. - Kandile, N. G. (2014): Unsaturated Polyesters / Layered Silicate Nanocomposites: Synthesis and Characterization. IOSR Journal of Applied Chemistry (IOSR-JAC), Vol. 7, No. 10, pp. 34-43.

[9] Khazaal, M. S. - Tomma, J. H. (2011): Synthesis and Characterization of Novel Schiff Bases Containing Isoxazoline or Pyrazoline. Ibn Al-Haitham Journal for Pure \& Applied Sciences, Vol. 24, No. 2, pp. 1-14.

[10] Salman, F. W. - Radhi, S. W. - Jodh, A. M. (2015): Preparation and study antibacterial activity of a new polymer. Journal of Babylon University, Pure and Applied Sciences, Vol. 23, No. 2, pp. 759-770.

[11] Al-Mulla, E.A. J. - Yunus, W. M. Z. - Ibrahim, N. A. (2010): Enzymatic synthesis of fatty amides from palm olein. Journal of Oleo Science, Vol. 59, pp. 59-64.

[12] Yunus, W. M. Z. - Ibrahim, N. A. - Mohm, Z. A. (2011): Epoxidized palm oil plasticized polylactic acid/fatty nitrogen compound modified clay nanocomposites: preparation and characterization. Korean Journal of Chemical Engineering, Vol. 28, No. 2, pp. 620-626. https://doi.org/10.1007/s11814-010-0373-6

[13] Yunus, W. M. Z. - Ibrahim, N. A. - Zaki, A. (2010): Difatty acyl urea from corn oil: synthesis and characterization. Journal of Oleo Science, Vol. 59, pp. 157-160.

[14] Phua, Y. J. - Chow, W. S. - Mohd Ishak, Z. A. (2013): Organomodification of Montmorillonite and Its Effects on the Properties of Poly(butylene succinate) Nanocomposites, Polymer Engineering and Science, Vol. 53, No. 9, pp. 1947-1957. https://doi.org/10.1002/pen.23460

[15] Mansor, B. A. - Wisam, H. H. - Nor Azowa B. I. - Emad, A. J. A. (2009): Modification of Montmorillonite by new surfactants. Journal of Engineering and Applied Science, Vol. 4, No. 3, pp. 184-188.

[16] Khalaf, A. I. - Hegazy, M. A. - El-Nashar, D. E. (2015): Synthesis and Characterization of Cationic Gemini Surfactant Modified Na-Bentonite and Its Applications for Rubber Nanocomposites. Polymer composites, Vol. 38, No. 2, pp. 396-403. https://doi.org/10.1002/pc.23598

[17] Guo, L. - Wu, S. - Zeng, F. - Zhao, J. (2006): Synthesis and Fluorescence property of terbium complex with novel Schiff-base macromolecular legend, European Polymer Journal, Vol. 42, pp. 1670-1675. https://doi.org/10.1016/j.eurpolymj.2006.01.025

[18] Ramachandranl, E. - Baskaran, K. - Natarajan, S. (2007): XRD, Thermal, FTIR and SEM studies on gel grown glycine crystals. Crystal Research and Technology, Vol. 42, No. 1, pp. 73-77.

https://doi.org/10.1002/crat.200610774

Ref.

Abd-Almutalib Al-Mosawy, Manar Ghyath - Al-Mulla, Emad A. Jaffa - Mohamad, Majed Jari: Bentonite-based organoclays using chalcone and azo dye as organophilic reagents

Építőanyag - Journal of Silicate Based and Composite Materials, Vol. 69, No. 2 (2017), 49-54. p. https://doi.org/10.14382/epitoanyag-jsbcm.2017.9

Bentonit alapú szerves agyagok szintézise kalkon és azovegyület szerves reagensekkel

A cikk szerves reagensekkel szintetizált szerves agyagok elôállítását és jellemzôit mutatja be. Az elôállított vegyületek struktúráját és a bentonit alapanyaghoz kapcsolódásának mértékét Fourier transzformációs infravörös spektroszkópiával (FTIR) és röntgendiffrakcióval (XRD) vizsgálták. Az FTIR és XRD vizsgálatok igazolták, hogy a szerves komponensek sikeresen megkötôdtek a bentonit agyagban. Termoanalitikai (TGA) vizsgálatokkal vizsgálták a vegyületek stabilitását. A TGA vizsgálatok rámutattak, hogy a szerves agyagok stabilitása jobb a tiszta bentoniténál. A szintetizált szerves agyagok alkalmazása sikeres lehet eldobható, lebomló nanokompozit csomagolóanyagok elóállítása során.

Kulcsszavak: nátrium bentonit, modifikálás, felületaktív anyagok, szerves kationok 